\title{
Whitespotted puffer Arothron hispidus, a new host for lymphocystis in Qingdao Aquarium of China
}

\author{
Xiu-zhen Sheng, Wen-bin Zhan*, Yue Wang \\ Laboratory of Pathology and Immunology of Aquatic Animals, LMMEC, Ocean University of China, 5 Yushan Road, \\ Qingdao 266003, PR China
}

\begin{abstract}
In April 2004 white nodular lesions were found on the fins of whitespotted puffer Arothron hispidus (Linnaeus). Diagnostic studies were carried out to confirm the disease using light and electron microscopy, histochemical methods and PCR. The results revealed that the nodules were composed of giant cells up to $400 \mu \mathrm{m}$ in diameter. These cells were surrounded by a periodic acid-Schiff (PAS)-positive hyaline capsule containing dot-shaped, Feulgen-positive inclusion bodies in the cytoplasm and an irregular nucleus. Numerous virus particles $200 \mathrm{~nm}$ in diameter and with hexagonal profiles were observed in the cytoplasm. These features were consistent with those of lymphocystis disease. Additionally, based on the gene sequences of major capsid protein (MCP) of lymphocystis disease virus (LCDV) from Japanese flounder Paralichthys olivaceus, 2 pair primers were designed; after a nested PCR was performed for detection of LCDV in A. hispidus, a positive amplified product was obtained showing the presence of LCDV. Therefore, the white nodules were the lymphocystis lesions caused by LCDV infection and $A$. hispidus was demonstrated to be a new host for LCDV.
\end{abstract}

KEY WORDS: Whitespotted puffer · Arothron hispidus $\cdot$ Lymphocystis disease · Histopathology · PCR $\cdot$ Histochemistry

Resale or republication not permitted without written consent of the publisher

\section{INTRODUCTION}

Lymphocystis disease virus (LCDV) is the causative agent of lymphocystis disease. It has a worldwide distribution and has infected over 125 species of fish belonging to 42 families including feral, cultured and ornamental fish. Lawler et al. $(1977,1978)$ reported the occurrence of lymphocystis in over 8 species of fish, including the Koran angelfish Pomacanthus semicirculatus (Cuvier), the queen angelfish Holacanthus ciliaris (Linnaeus), the Moorish idol Zanclus canescens (Linnaeus) and the foureye butterflyfish Chaetodon capistratus (Linnaeus), all of which are commercially important aquarium fishes. Giavenni (1982) found 71 cases of lymphocystis disease in 29 fish species in tropical saltwater aquarium fishes during a 2 year period. Furthermore, many other aquarium fish species, including squirrelfish Sargocentron punctatissimum, snakeskin gourami Trichogaster pectoralis, quillback rockfish
Sebastes maligar, and glassfish Chanda ranga, have been reported as lymphocystis hosts (McCosker et al. 1976, Curry 1977, Richards 1977, Leibovitz 1980, Paperna et al. 1987, Anderson et al. 1988, Williams et al. 1996). Also, lymphocystis disease was found in the farm-reared tropical ornamental fish scalare Pterophyllum scalarae and gourami Trichogaster spp. (Paperna et al. 2001). In China lymphocystis disease has been reported in about 10 species of cultured fish (Zhang et al. 1992, Qu et al. 1998, Sheng et al. 2006), but not in aquarium fish species until now.

In April 2004 white nodules were found developing on the fins of whitespotted puffer Arothron hispidus reared in the Qingdao Aquarium of China. The lesions were not observed in other fish species in the aquarium. To confirm the type of the disease several diagnostic studies were performed; as a result, we proved that it was lymphocystis disease and $A$. hispidus was a new host for LCDV. 


\section{MATERIALS AND METHODS}

Arothron hispidus were reared in the aquarium tank at $25 \pm 1^{\circ} \mathrm{C}$ in the Qingdao Aquarium of China and fed small fish and sleeve-fish. The diseased fish averaged about 25 to $30 \mathrm{~cm}$ in body length. The white nodules first appeared in April 2004, with the largest size being the $1 \times 1 \mathrm{~cm}$. They appeared smooth and dense and only occurred on the fish's pectoral fins. The nodules gradually decreased in size and by the end of June only one small white dot was visible.

Paraffin sectioning and histochemical staining. White nodules on the fins were dissected along with the connected skin, fixed with Bouin's fixative, processed for routine paraffin sectioning (5 $\mu \mathrm{m}$ in thickness) and stained with H\&E for histopathological observation. Histochemical methods were used to indicate the inclusion bodies (Mann's method), DNA (Feulgen reaction) and polysaccharide (periodic acid-Schiff [PAS] reaction).

Ultrathin sectioning. Nodule samples were collected and fixed in $2.5 \%$ glutaraldehyde in phosphatebuffered saline (PBS) $\left(0.1 \mathrm{~mol} \mathrm{l}^{-1}, \mathrm{pH} 7.4\right)$ for $2 \mathrm{~h}$ at $4^{\circ} \mathrm{C}$, postfixed in $1 \%$ osmium tetroxide in PBS for $1 \mathrm{~h}$ at $4{ }^{\circ} \mathrm{C}$, dehydrated in an ascending ethanol series, infiltrated and embedded in Epon epoxy resin according to standard procedures. Ultrathin sections were doublestained with uranyl acetate and lead citrate, and observed and photographed with a Hitachi H-7000 transmission electron microscope (TEM).

Nested PCR assay for the detection of LCDV in Arothron hispidus. The skin samples of healthy $A$. hispidus and the white nodules of diseased fish were removed and the genomic DNA of the samples was extracted according to the method of Sambrook \& Russell (2001). The DNA extracts from white nodules of $A$. hispidus were used for nested PCR for the detection of LCDV with the DNA extracts from the skin of healthy A. hispidus used as a negative control, and the LCDV DNA from Japanese flounder Paralichthys olivaceus isolated in our laboratory used as a positive control.

The primer sets for the PCR were designed based on the gene sequence of the major capsid protein (MCP) of LCDV from Paralichthys olivaceus (GenBank: AF126405, Xu et al. 2000). The primers P1 (5'-CAT CAT GCC TTT GAC AGC-3') and P2 (5'-GGA TCA GCA ATA CCC-3') were designed for the first round of nested PCR and expected to generate a 384 bp fragment product; primers P3 (5'-TCC ACC GTC AAA GAT TAC-3') and P4 (5'-CAA TTC CAC CGT CAA AGA-3') were designed to amplify a $173 \mathrm{bp}$ product for the second round of nested PCR.

The primary and secondary PCR of the nested PCR was performed on a GeneAmp PCR System 9700 (Applied Biosystems) under the same conditions: an initial denaturation at $94^{\circ} \mathrm{C}$ for $5 \mathrm{~min}$, followed by 30 amplification cycles $\left(94^{\circ} \mathrm{C}\right.$ for $2 \mathrm{~min}, 49^{\circ} \mathrm{C}$ for $1 \mathrm{~min}$ and $72^{\circ} \mathrm{C}$ for $1 \mathrm{~min}$ ) and a final extension step at $72^{\circ} \mathrm{C}$ for $5 \mathrm{~min}$. In the primary $\mathrm{PCR}$, the reaction mixture in a final volume of $50 \mu$ contained $1 \times$ reaction buffer (10 mmol $\mathrm{l}^{-1}$ Tris- $\mathrm{HCl} \mathrm{pH}$ 9.0, $50 \mathrm{mmol} \mathrm{l^{-1 }} \mathrm{KCl}_{\text {, }}$ $1.5 \mathrm{mmol} \mathrm{l}^{-1} \mathrm{MgCl}_{2}, 0.1 \%$ Triton X-100), $0.5 \mu \mathrm{mol} \mathrm{l} \mathrm{l}^{-1}$ of each primer (P1/P2), 2 units Taq-polymerase (Sangon), $1.5 \mathrm{mmol} \mathrm{l}^{-1} \mathrm{Mg}^{2+}, 200 \mu \mathrm{mol} \mathrm{l}{ }^{-1} \mathrm{dNTP}$ and $1 \mu \mathrm{g}$ of DNA template. For the secondary PCR, $1 \mu \mathrm{l}$ of 1:100 dilution of the reaction mixture from the primary PCR was used as the template; the PCR was carried out under the same conditions as in the first cycle, but in the presence of the primers P3/P4. Amplification products were electrophoresed in a $1.5 \%$ agarose gel using pBR322DNA/AluI (BBI) as a marker, and visualized with a UV transilluminator after ethidium bromide staining (1 $\left.\mathrm{mg} \mathrm{ml}^{-1}\right)$ (Amersco).

\section{RESULTS}

\section{Histopathologic features of white nodules from Arothron hispidus}

The white nodules on the fins of Arothron hispidus were composed of enlarged cells in the connective tissue of the dermis with the largest size being $400 \mu \mathrm{m}$ in diameter. Abundant connective tissues were evident among these cells and many fibres were distributed in the connective tissue, which might be the reason why the nodules appeared dense and smooth. Infiltration by many inflammatory cells into the connective tissue and around the giant cells was observed. The enlarged cells had irregular nuclei in which the marginated and condensed chromatin usually connected with the nuclear membrane. The cytoplasm was basophilic and stained unevenly in color by hematoxylin. Abundant strong basophilic dot-shaped substances were located at the cell periphery. A distinctive thick hyaline capsule appeared outside of the cell membrane (Figs. 1 $\& 2$ ). The senile cells, which usually were surrounded by many inflammatory cells and fibres that formed a collar, eventually ruptured and released the cytoplasm, leaving a cavity containing cellular debris (Fig. 3). The areas where lymphocystis cells had disappeared were observed to be light in color (Fig. 4). No lymphocystis cells could be seen in the June samples.

Histochemical staining with Mann's method stained the basophilic substances located at the cell periphery (as seen in H\&E stained sections) blue, indicating they were inclusion bodies. The inclusion bodies, the chromatin and the cytoplasm of the giant cells were Feulgen-positive, indicating DNA was present (Fig. 5). The hyaline capsule stained purple with the PAS reaction, showing it contained polysaccharides (Fig. 6). 

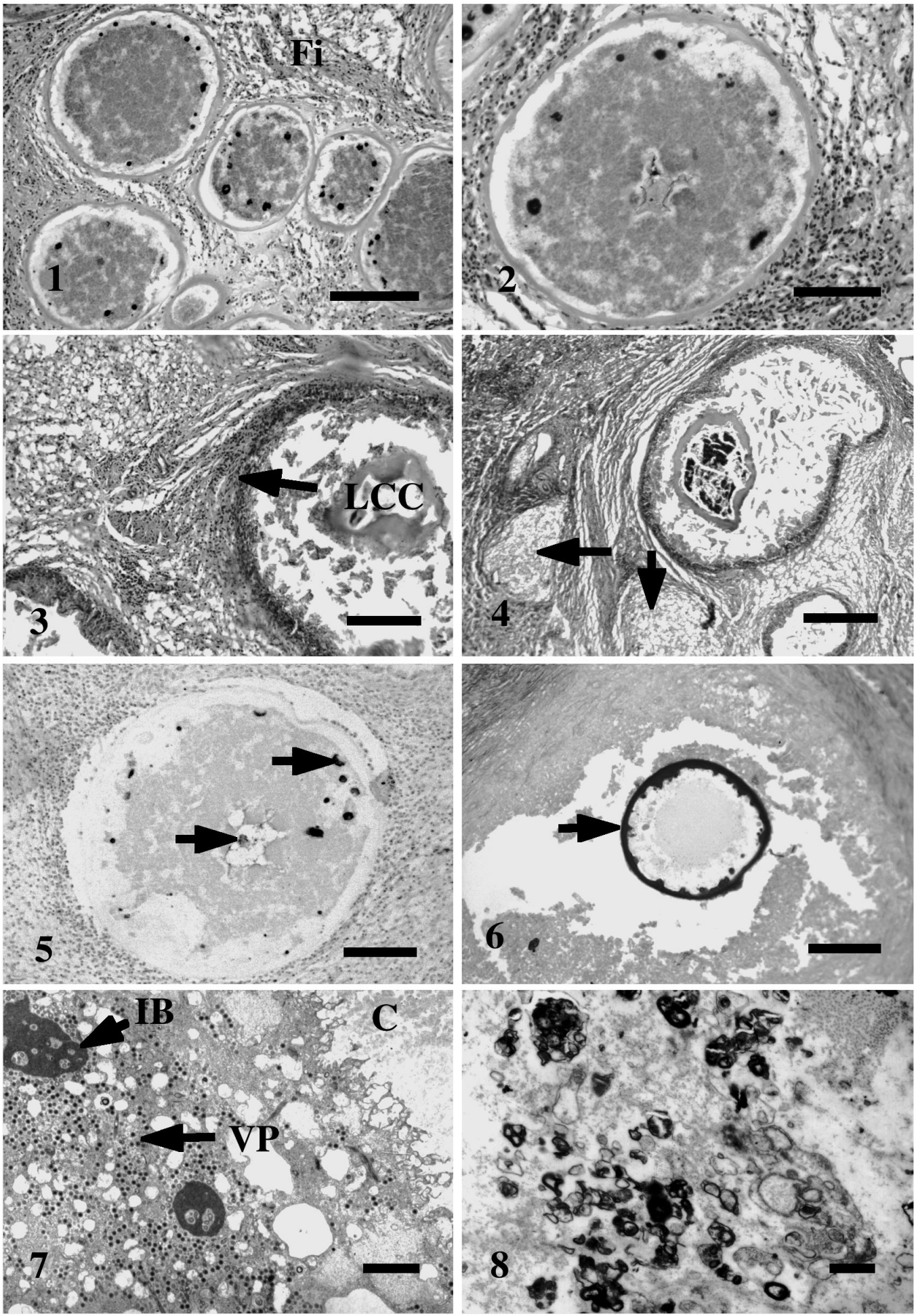

Fig. 1 to 8. Lymphocystis disease in Arothron hispidus. Fig.1. Lymphocystis cells and fibre (Fi) in the connective tissue. Scale bar $=200 \mu \mathrm{m}$. Fig. 2. Enlargement of lymphocystis cell. Scale bar $=100 \mu \mathrm{m}$. Fig. 3. Ruptured senile lymphocystis cells $(\mathrm{LCC})$ and inflammatory cells (arrow) surrounding them. Scale bar $=200 \mu \mathrm{m}$. Fig. 4. Light-colored areas (arrows) show where lymphocystis cells had ruptured and disappeared. Scale bar $=200 \mu \mathrm{m}$. Fig. 5. Feulgen reaction showing the Feulgen-positive cytoplasm, chromatin in the nucleus and inclusion bodies in lymphocystis cells (arrows). Scale bar $=150 \mu \mathrm{m}$. Fig. 6. Periodic acid-Schiff (PAS) reaction showing the positive-stained capsule (arrow). Scale bar $=200 \mu \mathrm{m}$. Fig. 7. Ultrastructure of lymphocystis cells showing virus particles (VP), inclusion body (IB) in the cytoplasm and the capsule (C) outside the cells. Scale bar $=2 \mu \mathrm{m}$. Fig. 8 . Cellular residuals distribute in the connective tissue in June sample. Scale bar $=500 \mathrm{~nm}$ 
Under TEM numerous mature or immature virus particles about $200 \mathrm{~nm}$ in diameter and with hexagonal profiles were observed in the cytoplasm of the enlarged cells, but not in the nucleus (Fig. 7). High electron-dense inclusion bodies were located at the cell periphery with virions budding from the surface of the cell. Various electron-lucent vacuoles were present in the cytoplasm, especially at the cell periphery. The capsule outside the enlarged cells was homogeneous with low electron density. In the June samples many cellular residuals were distributed in the connective tissue and no viruses were observed (Fig. 8).

\section{Detection of LCDV in Arothron hispidus by nested PCR}

A nested PCR assay was tested using 10-fold dilutions of LCDV DNA from Paralichthys olivaceus. Primers P1/P2 for the first round of PCR amplified a $348 \mathrm{bp}$ fragment (Fig. 9A) and primers P3/P4 for the second round of $\mathrm{PCR}$ produced a $173 \mathrm{bp}$ fragment (Fig. 9B); the sizes of amplifications were consistent with those predicted. A minimum of $1 \times 10^{-4} \mu \mathrm{g}$ of

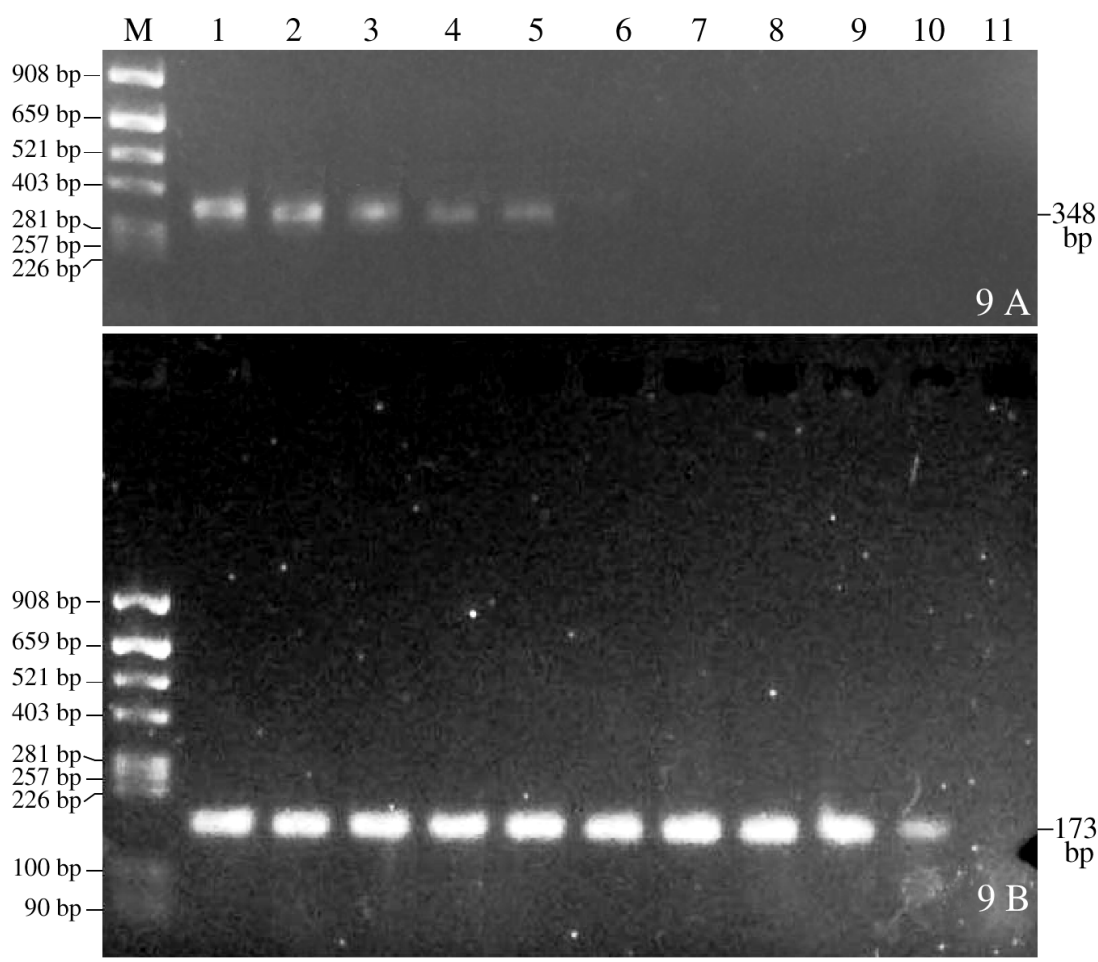

Fig. 9. Agarose gel of the nested PCR using lymphocystic disease virus (LCDV) DNA of Japanese flounder. Serial 10-fold dilutions of LCDV DNA $10^{0}$ to $10^{-10}$ were subjected to (A) the first round PCR and (B) the second round PCR and amplified a 384 and $173 \mathrm{bp}$ fragment, respectively. Lane M: pBR322 DNA/Alu I marker; Lanes 1-11: virus extracted DNA with serial 10 -fold dilution of initial concentration of $1 \mu \mathrm{g}$
LCDV DNA were required to get a positive signal in the primary PCR and the detection limit was $1 \times$ $10^{-9} \mu \mathrm{g}$ of viral DNA in the secondary PCR.

After the second round amplification of nested PCR, a $173 \mathrm{bp}$ fragment was obtained from the DNA extracts from the April nodule samples with the same molecular weight as the positive control (Paralichthys olivaceus LCDV DNA), suggesting the existence of LCDV DNA in Arothron hispidus; no corresponding band was observed in the negative control (the skin DNA of healthy $A$. hispidus) and the DNA extracts from the June nodules (Fig. 10). Therefore, lymphocystis virus particles existed in the nodules of $A$. hispidus in April; the nodules were caused by the LCDV infection and they regressed by the end of June.

\section{DISCUSSION}

The results of histopahology, histochemistry and TEM revealed that the nodules on the fins of Arothron hispidus have the common histological features of lymphocystis disease such as cellular hypertrophy, enlarged nucleus, Feulgen-positive cytoplasmic inclusion bodies and cell enclosure by a distinctive PAS-positive hyaline capsule. Also, virus particles about $200 \mathrm{~nm}$ in diameter with hexagonal profiles in the cytoplasm of the enlarged cells were present, indicating that the white nodules in $A$. hispidus were lymphocystis lesions.

The MCP of iridoviruses is a suitable target for the study of viral evolution since it contains highly conserved domains (Tidona et al. 1998). The MCP of LCDV from Paralichthys olivaceus in China shows a high identity to those of LCDV-1 and other iridoviruses (Xu et al. 2000, He et al. 2001, 2002, Zhang et al. 2004). Based on the gene sequence of the MCP of LCDV (GeneBank: AF126405, Xu et al. 2000), 2 primer pairs were designed and applied in this study, and a $348 \mathrm{bp}$ fragment in the first round PCR and a $173 \mathrm{bp}$ fragment in the second round PCR were obtained. For the detection of the LCDV in the nodules of Arothron hispidus, the nested PCR amplified a $173 \mathrm{bp}$ fragment in the April samples similar to that of LCDV DNA from $P$. olivaceus, revealing the existence of LCDV. Therefore, the nested PCR assay using the primers derived from the MCP of LCDV from $P$. olivaceus is an effective method for the diagnosis of lymphocystis disease. 


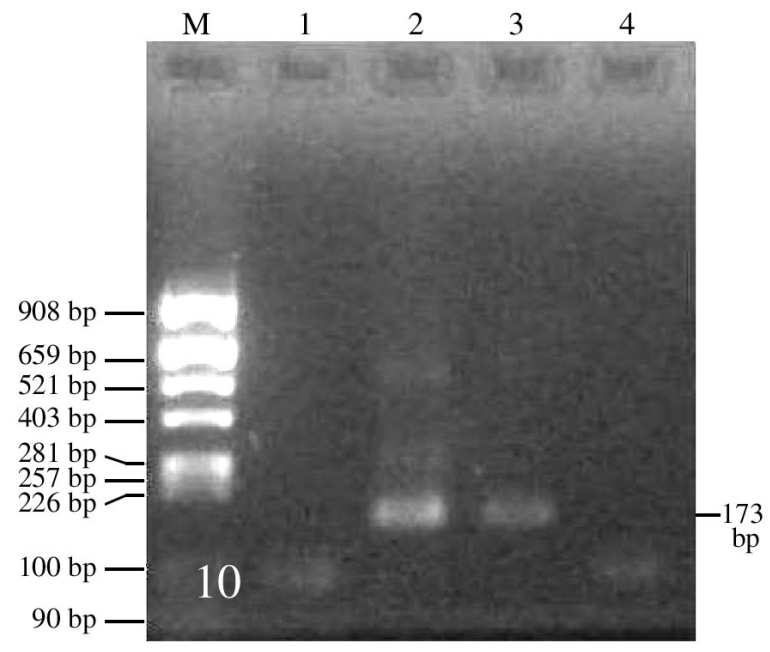

Fig. 10. Detection of LCDV in the nodules of Arothron hispidus using nested PCR. Lane M: marker; Lane 1: negative control (the skin DNA of healthy A. hispidus); Lane 2: positive control (DNA of LCDV from Paralichthys olivaceus); Lane 3: extracted DNA of white nodule from A. hispidus in April. Lane 4: extracted DNA of white nodule from A. hispidus at the end of June

Sano et al. (1994) reported that the progression and regression of lymphocystis was closely related to rearing water temperature. Lesions were visible when water temperature was less than about $22^{\circ} \mathrm{C}$ in October and not visible when temperatures were greater than about $20^{\circ} \mathrm{C}$ in June and July. In both seasons when the animals were kept experimentally in water over $25^{\circ} \mathrm{C}$, the lesions regressed remarkably in 3 to 5 wk. In China lymphocystis disease breaks out in fish throughout the year. Qu et al. (1999) found that the regression of lymphocystis seemed to be related to the course of the disease, and regression occurred 2 to 3 mo after the onset of the disease. In the present study, Arothron hispidus were reared at $25 \pm 1{ }^{\circ} \mathrm{C}$ and the water temperature did not change with the season. Lymphocystis nodules were present in early April and regressed by the end of June, which suggested that the occurrence of the disease was not strictly related to the rearing temperature, but related to the course of the disease as suggested by Qu et al. (1999).

Colorni et al. (1995) showed lymphocystis nodules to be present in the skin and sometimes in the internal tissues of red drum Sciaenops ocellatus. We have previously observed hypertrophic lymphocystis cells in the gill, submucosa of the intestine, spleen, peripheral portion and the surface of the head kidney, and the adjacent mesenteries of the liver and intestine in Paralichthys olivaceus (Sheng et al. 2006), but in the present study lymphocystis nodules were observed only on the pectoral fins of Arothron hispidus. Internal tissues were not sampled and further study is needed to confirm or deny the existence of internal nodules in this species.

Lymphocystis disease is viral, but the infection rate is increased by stress factors such as malnutrition, dense host population or water pollution (Sindermann1996, Dethlefsen et al. 2000, Essbauer et al. 2004). The cause of lymphocystis disease in Arothron hispidus has not been determined definitively, but it may originate from virus particles in the water or food. Since there are no effective medications for lymphocystis disease, the best preventive measures are to remove the diseased fish from the population or keep them under optimal, stress-free conditions with good nutrition to maintain a healthy immune system.

Acknowledgements. This work was supported by grants from the National Natural Science Foundation of China (30271016) and funded by a Project under the National High Technology Development Program of China (863)(2006AA100306).

\section{LITERATURE CITED}

Anderson BE, Brock JA, Hayashi T, Teruya S, Nakaqawa LK (1988) The occurrence of lymphocystis in a new host species, Sargocentron punctatissimum Cuvier and Valenciennes, collected and maintained in Hawaii. Pac Sci 42: $214-216$

Colorni A, Diamant A (1995) Splenic and cardiac lymphocystis in the red drum, Sciaenops ocellatus (J). J Fish Dis 18: $467-474$

Curry C (1977) Diseases of salt water fish. Iowa State Univ Vet 39:26-30

Dethlefsen V, Lang T, Koves P (2000) Regional patterns in prevalence of principal external diseases of dab Limanda limanda in the North Sea and adjacent areas 1992-1997. Dis Aquat Org 42:119-132

Essbauer S, Fischer U, Bergmann S, Ahne W (2004) Investigations on the ORF $167 \mathrm{~L}$ of lymphocystis disease virus (Iridoviridae). Virus Genes 28:19-39

Giavenni R (1982) Notes on the more diffuse verifiable disease of ornamental fish. Marine tropical fish. Riv Ital Piscic Ittiopatol 17:33-36

He JG, Deng M, Weng SP, Li Z, Zhou SY, Long QX, Wang XZ, Chan $S$ (2001) Complete genome analysis of the mandarin fish infectious spleen and kidney necrosis iridovirus. Virology 291:126-139

He JG, Lü L, Deng M, He HH and 6 others (2002) Sequence analysis of the complete genome of an iridovirus isolated from the tiger frog. Virology 292:185-197

Lawler AR, Ogle JT, Donnes C (1977) Dascyllus spp: new hosts for lymphocystis, and a list of recent hosts. J Wildl Dis 13:307-311

Lawler AR, Ogle JT, Donnes C (1978) New hosts for lymphocystis. Gulf Res Rep 6:183-184

Leibovitz L (1980) Lymphocystis disease. J Am Vet Med Assoc 176:202

McCosker JE, Lagios MD, Tucker T (1976) Ultrastructure of lymphocystis virus in the quillback rockfish, Sebastes maliger, with records of the infection in other aquarium held fishes. Trans Am Fish Soc 105:333-337 
Paperna I, Ventura TM, de Matos AP (1987) Lymphocystis infection in snakeskin gourami, Trichogaster pectoralis (Regan), (Anabantidae). J Fish Dis10:11-19

Paperna I, Vilenkin M, de Matos AP (2001) Iridovirus infections in farm-reared tropical ornamental fish. Dis Aquat Org 48:17-25

Qu J, Jiang YL, Shen HP, Wang H, Liu H, Lian JH, Pan YJ, Zheng LL (1998) A preliminary report on lymphocystis disease in Paralichthys olivaceus. Chin Anim Quarantine 15(2):1-3 (Chinese in English abstract)

Qu LY, Zhang JX, Sun XQ (1999) Epidemiological and histopathological study on the lymphocystis disease of cultured left-eyed flounder Paralichthys olivaceus. J Oceanogr Huanghai Bohai Seas 17(21):43-47 (in Chinese with English abstract)

Richards R (1977) Diseases of aquarium fish, 2. Skin diseases. Vet Rec 101:132-135

Sambrook J, Russell DW (2001) Molecular cloning: a laboratory manual, 3rd edn. Cold Spring Harbor Laboratory Press, Cold Spring Harbor, NY

Sano T, Fukuda H, Komatsu T (1994) Thermal effect on lymphocystis of flounder (Paralichthys olivaceus). In: International Symposium on Aquatic Animal Health: programs

Editorial responsibility: Jo-Ann Leong,

Kaneohe, Hawaii, USA and abstracts. University of California, School of Veterinary Medicine, Davis, CA, p 4-8

Sheng XZ, Zhan WB (2006) Histopathological studies on target organs of lymphocystis disease virus of fish. J Oceanogr Univ Chin 36(5):749-753 (in Chinese with English abstract)

Sindermann CJ (1996) Ocean pollution: effects on living resources and humans. CRC Press, Boca Raton, FL

Tidona CA, Schnitzler P, Kehm R, Darai G (1998) Is the major capsid protein of iridoviruses a suitable target for the study of viral evolution? Virus Genes 16:59-66

Williams EH Jr, Grizzle JM, Bunkley-Williams L (1996) Lymphocystis in Indian glassfish Chanda ranga imported from Thailand to Puerto Rico. J Aquat Anim Health 8:173-175

Xu HT, Piao CA, Jiang ZL, Wang WX (2000) Study on the causative agent of lymphocystic disease in cultured flounder, Paralichthys olivaceus, in Mainland China. Chin J Virol 16:223-226

Zhang QY, Xiao F, Xie J, Li ZQ, Gui JF (2004) Complete genome sequence of lymphocystis disease virus isolated from China. J Virol 78:6982-6994

Zhang YJ, Wu ZY (1992) Primary studies on the lymphocystis disease in marine fish. Fish Dis Study 14(4):7-9 (in Chinese with English abstract)

Submitted: May 17, 2006; Accepted: February 6, 2007 Proofs received from author(s): March 26, 2007 